\title{
Amino acid metabolism in tennis and its possible influence on the neuroendocrine system
}

\author{
H. K. Strüder PhD, W. Hollmann MD, J. Duperly MD and K. Weber MD \\ Institute for Cardiology and Sports Medicine, Institute for Sports Games, German Sports University, \\ Carl-Diem-Weg 6, 50933 Cologne, Germany
}

\begin{abstract}
To investigate amino acid metabolism during endurance exercise as well as its influence on plasma prolactin (PRL) we subjected eight nationally ranked tennis players (mean(s.d.) age 25.6(2.8) years, mean(s.d.) weight $83.9(5.7) \mathrm{kg}$, mean(s.d.) height $184.4(4.6) \mathrm{cm}$ ) to $4 \mathrm{~h}$ of continuous tournament tennis. Venous and capillary blood samples were taken before and after the exercise. Amino acids were measured by HPLC-fluorescence detection as o-phthalaldehyde derivatives; nonesterified fatty acids (NEFA), ammonia, total protein, glucose insulin and PRL by enzymatic methods. Exercise caused a decline of branched-chain amino acids (BCAA) by $28(14) \%$. Elevation of NEFA resulted in a significant mean(s.d.) increase of free tryptophan (TRP) $(9.7(2.6)[\mathrm{pmol} / \mu \mathrm{l}]$ vs $\mathbf{1 7 . 8 ( 6 . 4 )}$ [pmol/ $\mu$ l]. The mean(s.d.) ratio of free TRP:BCAA increased by $165 \%(90)$ which favours entry of free TRP into the brain. However, PRL did not change significantly. We conclude that during long-lasting interval sports BCAA contribute as energy substrates. Alterations in competition of amino acids at the blood-brain barrier favour entry of free TRP into the brain. PRL changes cannot be explained by the increase in plasma level of free TRP or the ratio of free TRP:BCAA.
\end{abstract}

Keywords: tennis, amino acids, free tryptophan, neurotransmitter, prolactin

Some amino acids function as precursors of brain neurotransmitters. Free tryptophan (TRP) is converted in the brain to serotonin (5-HT); tyrosine (TYR) to dopamine ${ }^{1}$. In animal studies, TRP administration was shown to raise brain TRP levels and accelerate brain 5-HT synthesis and release, because TRP hydroxylase - the rate-limiting enzyme for 5-HT synthesis - is not saturated ${ }^{2}$. Increased $5-\mathrm{HT}$ synthesis has been shown to be involved in neuroendocrine system modulations ${ }^{3}$. In man, intravenous administration of TRP at rest has been reported to induce an increase of prolactin (PRL) ${ }^{4}$.

The factors that cause PRL release during exercise are complex and depend on type, amount and length of the exercise. It was shown that PRL increase during intensive exercise is related to anaerobiosis ${ }^{5}$ and can be blunted by serotonergic antagonism ${ }^{6}$. The causes of PRL changes during endurance exercise

Address for correspondence: $\operatorname{Dr} H$. K. Strüder remain controversial. Studies report increases ${ }^{7,8}$ and decreases $^{5}$. Fischer et al. ${ }^{7}$ hypothesized that PRL increase during continuous endurance exercise may be directly influenced by the increase in plasma free TRP, mediated by the augmentation of nonesterified fatty acids (NEFA), and the decrease of plasma BCAA. This would favour the transport of free TRP into the brain, as free TRP and BCAA share the carrier for large neutral amino acids (LNAA) at the blood-brain barrier and competition for entry occurs ${ }^{9}$.

In the present study we investigated effects of amino acid metabolism and NEFA-induced increase of free TRP on PRL during long-lasting interval exercise.

\section{Method}

We subjected eight nationally ranked male players (mean(s.d.) age 25.6(2.8) years, mean(s.d.) weight $83.9(5.7) \mathrm{kg}$, mean(s.d.) height $184.4(4.6) \mathrm{cm}$ to $4 \mathrm{~h}$ of continuous single tournament tennis. The $4 \mathrm{~h}$ of exercise started with a warm-up period of $5 \mathrm{~min}$ at 10.00 a.m. and ended at 2.00 p.m. Water (ad libitum) was the only supplement allowed during the exercise. Venous blood samples were taken before the warm-up and immediately after the exercise in heparinized and EDTA-containing vacutainers. Glucose was measured from capillary blood from the hyperaemized earlobe. Plasma was prepared by standard methods and frozen and stored at $-20^{\circ} \mathrm{C}$ until analysis. Separation of free TRP was carried out immediately by centrifugation of the plasma through a cellulose membrane (10000 NMWL) in Ultrafree-CL filtercones (PLGC, Millipore, USA). Temperature and $\mathrm{pH}$ were not controlled during the procedure. Since all samples were analysed using exactly the same method, comparison of pre- and post-exercise values within this study is possible and conclusions are qualitatively valid ${ }^{10}$. Amino acids were measured by HPLC-fluorescence detection as o-phthalaldehyde derivatives (HPLC HP1090, Hewlett Packard) ${ }^{11}$. NEFA, glucose, ammonia, and total protein were analysed by enzymatic methods using a Cobas-Bio centrifugal analyser (Hoffmann La Roche, Switzerland) and commercial test kits. Ammonia values were corrected according to Fischer et al. ${ }^{12}$. PRL and insulin were determined with the enzyme-immunoassay ES300 (Boehringer, Germany). Changes in 
plasma volume were corrected by means of total protein (Table 1). Heart-rate was recorded every $15 \mathrm{~s}$ using a Sports Tester PS3000 (Unilife, Germany). Effective playing time (duration of rallies) was calculated with stop-watches. Food intake the night before the exercise as well as for breakfast $(2 \mathrm{~h}$ prior exercise) was analysed with a commercial computed program for amount of energy and percentage of carbohydrates, fat and proteins. Data given are mean(s.d.). The Student $t$ test was used for statistical analysis $\left({ }^{*}=P \leqslant 0.05,{ }^{*}=P \leqslant 0.01\right)$.

\section{Results}

The mean(s.d.) effective playing time during the $4 \mathrm{~h}$ of exercise was $39.26(2.27) \mathrm{min}$; the average heart-rate $133 / \mathrm{min}$. Table 1 shows the changes of the analysed parameters. The mean(s.d.) ratio of free TRP to BCAA increased significantly $(P<0.01)$ by $165(90) \%$. The slight increase of plasma PRL was not significant. In five subjects, PRL declined. No significant correlation was found between food intake prior to exercise (mean(s.d.) intake the night before: $1469 \mathrm{kcal}(634)$, $48(13) \%$ carbohydrates, 30(7)\% fat, $19(9) \%$ proteins; average intake for breakfast: $536(2.0) \mathrm{kcal}, 59(17) \%$ carbohydrates, $27(15) \%$ fat, $13(6) \%$ proteins) and change of any measured variables during the match.

\section{Discussion}

From a metabolic aspect, tennis is characterized by a dominantly anaerobic-alactacid transformation of energy during the mainly short and high intensity runs and stroke movements. After each rally, the energy is provided over aerobic transformation, so that the creatine/phosphate and adenosine-3phosphate, both of which had been reduced during the rally, can almost be rebuilt totally through oxidation. The process of glycolysis is seldomly required during a rally ${ }^{13}$. The typical tennis-specific movement pattern with an interval workload structure, which usually takes about $1-2 \mathrm{~h}$ but can also extend in the case of best-of-five matches to $4 \mathrm{~h}$ causes this steady fluctuation in the transformation of energy.

The plasma levels of amino acids after extremely long tennis matches are affected by compartmental shifts as well as muscle and liver metabolism. BCAA especially are oxidized during exercise in muscle glycogen depletion, and may function as an amino group donor for alanine synthesis from pyruvate and for the aspartate supply during the adenosinemonophosphate resynthesis ${ }^{14}$. The decline of BCAA indicates their involvement in muscle metabolism during interval exercises such as tennis, because liver uptake of these amino acids is insignificant. Excessive activation of the $\mathrm{BC}$-complex during exercise leads to a rapid irreversible removal of branched-chain-2-oxoacids and an increased flux through the coupled reversible $\mathrm{BCAA}$ aminotransferase reaction ${ }^{14}$. The increase in leucine oxidation in the muscle is closely related to the $\mathrm{BC}$-complex activation observed during exhausting exercise ${ }^{15}$. This greater BCAA metabolism also increases the amount of amino groups which have to be disposed of as alanine or glutamine. During exercise there is an increase in alanine release from skeletal muscle. However, in our study, the plasma levels probably decline due to the high liver uptake as well as decreased pyruvate production caused by glycogen depletion. Alanine is used as an

Table 1. Measured parameters before and after $4 \mathrm{~h}$ of continuous tennis

\begin{tabular}{|c|c|c|c|}
\hline & Before & After & \\
\hline & mean(s.d.) & mean(s.d.) & Significance \\
\hline Glutamate $[\mathrm{pmol} / \mu \mathrm{l}]$ & $45.28(18.84)$ & $46.63(8.91)$ & n.s. \\
\hline Serine $[\mathrm{pmol} / \mu \mathrm{l}]$ & $91.47(23.13)$ & 61.64(12.39) & $* *$ \\
\hline Histidine $[\mathrm{pmol} / \mu \mathrm{l}]$ & $84.18(17.85)$ & 69.32(9.99) & ** \\
\hline Glycine $[\mathrm{pmol} / \mu \mathrm{l}]$ & $304.35(42.08)$ & $210.28(31.23)$ & ** \\
\hline Threonine $[\mathrm{pmol} / \mu \mathrm{l}]$ & $152.66(22.77)$ & $98.07(22.47)$ & $* *$ \\
\hline Alanine $[\mathrm{pmol} / \mu \mathrm{l}]$ & 608.86(153.39) & $348.38(96.13)$ & $* *$ \\
\hline Arginine $[\mathrm{pmol} / \mu \mathrm{l}]$ & $89.09(21.71)$ & $73.18(22.31)$ & n.s. \\
\hline Tyrosine $[\mathrm{pmol} / \mu \mathrm{l}]$ & $78.59(10.43)$ & $68.43(8.97)$ & n.s. \\
\hline Valine $[\mathrm{pmol} / \mu \mathrm{l}]$ & $261.21(24.53)$ & 195.92(32.57) & $* *$ \\
\hline Methionine $[\mathrm{pmol} / \mu \mathrm{l}]$ & $43.94(6.93)$ & $33.97(7.44)$ & $*$ \\
\hline Tryptophan [pmol/ $/ \mathrm{l}]$ & $87.64(14.35)$ & 65.07(13.35) & ** \\
\hline Isoleucine $[\mathrm{pmol} / \mu \mathrm{l}]$ & 90.99(13.28) & $59.65(9.84)$ & $* *$ \\
\hline Phenylalanine $[\mathrm{pmol} / \mu \mathrm{l}]$ & 78.95(8.09) & 63.33(10.09) & * \\
\hline Leucine $[\mathrm{pmol} / \mu \mathrm{l}]$ & $162.08(24.04)$ & 109.38(15.45) & ** \\
\hline Free tryptophan $[\mathrm{pmol} / \mu \mathrm{l}]$ & $9.73(2.67)$ & $17.76(6.35)$ & ** \\
\hline $\mathrm{BCAA}[\mathrm{pmol} / \mu \mathrm{l}]$ & $514.28(58.03)$ & $364.96(56.52)$ & ** \\
\hline Free TRP/BCAA [pmol/ $/ \mu \mathrm{l}]$ & $0.019(0.005)$ & $0.051(0.021)$ & $* *$ \\
\hline Total protein [g/dl] & $7.04(0.27)$ & $7.26(0.27)$ & $*$ \\
\hline Glucose [mg/dl] & $84(15.11)$ & $66(11.11)$ & * \\
\hline Ammonia $[\mu \mathrm{mo} / \mathrm{l}]$ & $36.78(2.84)$ & $46.21(12.21)$ & n.s. \\
\hline NEFA $[\mathrm{mmol} / \mathrm{l}]$ & $0.22(0.13)$ & $1.86(0.61)$ & $* *$ \\
\hline Insulin $[\mu \mathrm{U} / \mathrm{ml}]$ & $10.17(2.73)$ & $3.37(0.96)$ & ** \\
\hline Prolactin [ng/ml] & $10.51(4.43)$ & $11.63(8.15)$ & n.s. \\
\hline
\end{tabular}

n.s., Not significant; ${ }^{*}, P<0.05 ;{ }^{* *} P<0.01$ 
important gluconeogenic substrate to support maximal glucose release from the liver during exhaustive exercise. The decline in plasma glucose during the match may reflect progressive substrate depletion and the need for resynthesis of glucose from precursors like alanine, glycerol or lactate ${ }^{15}$.

In an identical study design, Weber et al. ${ }^{16}$ have shown that in tennis - similar to continuous endurance sports - mean(s.d.) NEFA are significantly increased after $90 \mathrm{~min}(0.78 \mathrm{mmol} / 1(0.23))$ and $240 \mathrm{~min}$ $(1.97(0.81) \mathrm{mmol} / \mathrm{l})$. Due to the fact that in our study a similar elevation of NEFA was found after $4 \mathrm{~h}$ of exercise, we expect a significant NEFA augmentation for about $150 \mathrm{~min}$ in our experiment. As NEFA and TRP compete for binding to albumin, elevation of NEFA results in a significant increase in free TRP ${ }^{17}$. This increase in mean(s.d.) free TRP, in combination with the decrease of BCAA by $28(14) \%$, favours the entry of free TRP into the brain ${ }^{9}$. In addition, elevated blood ammonia levels have been linked to changes in transport activity across the blood-brain-barrier, enhancing the uptake of LNAA into the brain in exchange for the glutamine efflux ${ }^{18}$.

Earlier findings ${ }^{7}$ suggest that these peripheral changes should increase 5-HT synthesis, and thus PRL secretion. However, since PRL did not rise significantly, our data do not provide support for the hypothesis that PRL response to endurance exercise may be related to factors increasing free TRP transport across the blood-brain-barrier. Physiological increases in 5-HT synthesis do not affect PRL secretion under our conditions. Although the free TRP concentration is the rate limiting factor in the synthesis of 5-HT, this metabolic pathway does not occur uniformly in various regions of the brain. Bailey et al. ${ }^{19}$ showed a wide difference of 5-HT concentrations in the midbrain, hippocampus, hypothalamus and striatum of exhausted rats. Moreover, the concentration of 5-HIAA, a 5-HT metabolite, was not always related to the 5-HT concentration.

The factors that trigger PRL release during endurance exercises are complex and cannot be reduced to a simple causal relationship with plasma free TRP level. In our study, the plasma ratio of TYR: BCAA increased, which affects TYR transport across the blood-brain barrier. Hypothalamic dopamine is a major prolactin-inhibiting factor ${ }^{20}$, and its synthesis is favoured by higher TYR availability in the brain. Moreover, endogenous opioids, augmented betaendorphin secretion and catecholamines can have an influence on PRL secretion during exercise ${ }^{21}$.

We conclude, that independent of extreme blood glucose depletion, and without leading to significant ammonia accumulations, most plasma amino acids decrease during long-lasting interval exercise and may, in the case of BCAA, contribute as energy substrates. Alterations in competition of amino acids at the blood-brain barrier favour the entry of free TRP into the brain. PRL changes are not directly influenced by NEFA-induced increases in plasma free TRP or the ratio of free TRP/BCAA under conditions such as ours. Further investigation is necessary to clarify the mechanisms of individually different prolactin response of the hypothalamic-pituitary axis during endurance exercise.

\section{Acknowledgements}

We are indebted to Professor Dr M. Donike and Dr A. Gotzmann (Institute for Biochemistry, Geman Sports University) for amino acid analyses.

\section{References}

1 Fernstrom JD. Role of precursor availability in control of monoamine biosynthesis in brain. Physiol Rev 1983; 63: 484-546.

2 Fernstrom JD, Wurtman RJ. Brain serotonin content: physiological dependence on plasma tryptophan levels. Science 1971; 173: 149-52.

3 Chaouloff F. Physical exercise and brain monoamines: a review. Acta Physiol Scand 1989; 137: 1-13.

4 Charney DS, Heninger GR, Reinhard JF, Sternberg DE, Hafstead KM. The effect of intravenous L-tryptophan on prolactin and growth hormone and mood in healthy subjects. Psychopharmacology 1982; 77: 217-22.

5 De Meirleir KL, Baeyens L, L'Hermite-Balériaux M, L'Hermite M, Hollmann W. Exercise-induced prolactin release is related to anaerobiosis. J Clin Endocrinol Metab 1985; 60: 1250-2.

6 De Meirleir KL, L'Hermite-Balériaux M, L'Hermite M, Rost $R$ Hollmann W. Evidence for serotoninergic control of exerciseinduced prolactin secretion. Horm Metabol Res 1985; 17: 380-1.

7 Fischer HG, Hollmann W, De Meirleir K. Exercise changes in plasma tryptophan fraction and relationship with prolactin. Int J Sports Med 1991; 12: 487-9.

8 Johannessen A, Hagen C, Galbo H. Prolactin, growth hormone, thyrotropin, 3, 5, 3'-triiodothyronine, and thyroxine responses to exercise after fat- and carbohydrate-enriched diet. J Clin Endocrinol Metab 1991; 52: 56-61.

9 Pardridge W. Brain metabolism: a perspective from the blood-brain barrier. Physiol Rev 1983; 63: 1481-535.

10 Curzon G. Methodological problems in the determination of total and free plasma tryptophan. J Neural Trans 1979; 15: 221-6.

11 Schuster R. Determination of amino acids in biological, pharmaceutical, plant and food samples by automated precolumn derivatization and high-performance liquid chromatography. J Chromatography 1988; 431: 271-84.

12 Fischer $\mathrm{HG}$, Mader A, Hollmann W. Pilotstudie zur enzymatischen Bestimmung von Ammoniak aus Ohrkapillarblut. Dtsch Z Sportmed 1990; 41: 196-9.

13 Weber K. Das Beanspruchungsprofil im Tennissport aus ieistungsphysiologischer Sicht. In: Küsswetter W, Zacher J, Sell S. Tennis und Sportmedizin. Stuttgart, Germany: Georg Thieme Verlag, 1990.

14 Wagenmakers AJM, Coakley JH, Edwards RHT. Metabolism of branched-chain amino acids and ammonia during exercise: clues from McArdle's disease. Int J Sports Med 1990; 11: (Suppl. 2) 101-13.

15 Hood DA, Terjung RL. Amino acid metabolism during exercise and following endurance training. Sports Med 1990; 9: 23-35.

16 Weber K, Ferrauti A, Strüder HK. Fettverbrennung im Tennis. Leistungs- und präventivmedizinische Aspekte. 33. Deutscher Sportärztekongress in Paderborn (14.-17.10.1993) (in press).

17 McMenamy RH, Oncley JL. The specific binding of Ltryptophan to serum albumin. J Biol Chem 1958; 233: 1436-47.

18 Banister EW, Rajendra W, Mutch B. Ammonia as an indicator of exercise stress implications of recent findings to sports medicine. Sports Med 1985; 2:34-46.

19 Bailey SP, Davis M, Ahlborn EN. Neuroendocrine and substrate responses to altered brain 5-HT activity during prolonged exercise to fatigue. J Appl Physiol 1993; 74: 3006-3012.

20 Hackney AC, Sinning WE, Bruot BC. Hypothalamicpituitary-testicular axis function in endurance-trained males. Int I Sports Med 1990; 11: 298-303.

21 Yen SSC. Neuroendocrine regulation of gonadotropin and prolactin secretion in women: disorders in reproduction. In: Vaitukaitis JL, ed. Current Endocrinology. New York, USA: Elsevier Biomedical, 1982; 357-88. 